Journal of Teacher Education for Sustainability, vol. 12, no. 1, pp. 37-50, 2010

\title{
INSPIRING TEACHERS FOR ENERGY EDUCATION: AN ILLUSTRATIVE CASE STUDY IN THE LATVIAN CONTEXT
}

\author{
Anita Pipere, Rudite Grabovska and Lolita Jonāne \\ Daugavpils University, Latvia
}

\begin{abstract}
Energy education has become a priority in light of the aims and tasks of the second half of UNESCO Decade of Education for Sustainable Development. This paper focuses on the case of inspiring teachers for energy education in the Latvian context, implemented within the COMENIUS project Inspire School Education by Non-formal Learning. The structure and content aspects of the in-service teacher training course are provided after the introduction to the theme. The methodological approach used in this study is integration of illustrative case study with the elements of programme implementation and programme effects case study. The data were collected by survey, focus group and questionnaire to obtain the teachers' feedback on the training course, its materials and to receive the teachers' self-evaluation on the implementation of the lesson units at their schools. It was concluded that the course had been very successful both from the point of view of the teachers and the course leaders. The described case study could serve as an example for those who would be interested in the design and implementation of similar courses in other contexts and circumstances.
\end{abstract}

Key words: teachers, energy education, training course, lesson unit, case study, sustainable development

Inspiring teachers for energy education: An illustrative case study in the Latvian context

At the onset of the first half of the Decade of Education for Sustainable Development 2005-2014 (DESD), teacher education institutions were transforming their strategy, study programmes and curricula towards sustainability (UNESCO, 2005, 2007, 2009a). In teacher education, sustainable development (SD) is a crosscutting theme with relevance to all disciplines and sectors enabling the learners to bridge the gap between the theory and practice. Teacher education institutions have a particular role in the global education community and the potential to bring change in educational systems (Richardson, 2001) and in shaping the capacity of future generations.

Lately, energy education has appeared among the priorities in sustainability-oriented teacher education. Energy is the central issue to SD and poverty reduction efforts. It affects all aspects of development - social, economic and environmental - including 
livelihoods, access to water, agricultural productivity, health and population levels (United Nations, 1992). In response to global issues, attention has been given to energy education on different levels. Energy education refers to the studies that promote an energy conscious and educated society by the mastering of energy efficiency and renewable energy topics, and these studies integrate economic, environmental, political, social and cultural aspects of human development.

Among others, science subjects and science teachers should raise the comprehension in school students of all ages about energy production, transformation and usage and the consequences of these processes are a primary concern. Energy education is one of the possibilities for developing a student's scientific literacy. Science teachers are critically important in informing and facilitating trans-disciplinary understandings, values, commitment and practice of different learning activities. Besides, especially non-formal energy education has a great potential for career guidance towards the university studies in engineering and technology.

In the context of SD, energy education should provide a balance between theory and practical aspects. Understanding the capabilities, costs and impacts of the wide variety of energy sources (renewable and non-renewable) that are or will be available and the consequences of choosing between them can develop valuable life skills for school children. According to European Communities (2006), energy education should also reflect local availability of and requirements for energy, together with local climatic and cultural characteristics. However, the educational content and learning activities for energy education should remain consistent with national and international priorities, reflecting the values of "thinking globally, acting locally" (ibid.). These educational trends require educators' comprehension of these education goals and professional competence to implement them. So, energy education should aim for the development of sustainability-oriented habits of energy usage, the mastering of scientific literacy and the evoking of interest to study engineering and technology.

To implement sustainability, numerous regional ESD networks, projects and programmes have been launched (UNESCO, 2009b). Different resources have been developed at international, regional and national levels, including tools for setting up projects and lesson plans at school and outside the classroom that could be adapted to different contexts and disseminated through educational networks and platforms. However, there is a visible need to enhance the scope of themes and availability of innovative practical materials for teachers especially in relation to such an urgent topic as energy education. In Latvia, the energy topic is included in educational guidelines side by side with other important topics connected with environmental education and education for sustainable development. However, in Latvia only a few out-of-school educational places could be mentioned that carry out educational functions regarding energy. These places mostly do not yet have elaborated teaching units about energy. The educational activities on energy are not on a regular basis and, as the research shows, this topic is not among the most popular ones for teachers (INSPIRE, 2008). Therefore, the project INSPIRE was a very timely and relevant contribution in the development of energy education, especially in Latvia.

The project Inspire School Education by Non-formal Learning (INSPIRE, 2008, 2009) has been conceived on the basis of the perceived need to foster non-formal learning on renewable energy and climate change. The project envisages multilevel and crossrelational interactions between the educational system experience in different countries, 
between researchers, teacher trainers, teachers and students, between the teachers of different subjects, class teachers and the staff of out-of-school places and also between the idea of SD and the possibilities of its realization in relation to renewable energy and climate changes. The approach of energy and climate issues covers both social and scientific competences and - regarding the threat of climate change - also outlines some of the European problems to be solved. The main results of the project - the lesson units for schools and out-of-school places and the teacher training courses - are based on the analysis of the existing situation that covers the main components, priorities and ongoing initiatives globally and in the project countries (Germany, Poland, Latvia), the differences in conceptual approaches to the topic, best practice examples and the major challenges and needs of schools and out-of-school places in relation to the project theme (Pipere, Jonāne, Salītis, Kokina, Grabovska, Kravale-Pauliņa, 2009; Jonāne \& Salītis, 2009; Kravale-Paulina \& Kokina, 2010).

Each partner country created five innovative lesson units on climate change, renewable energies and efficient energy use for out-of-school places that could be integrated into the curricula of school education. Eight primary school and seven secondary school lesson units were developed for children from 5 to 18 years with different durations: from 2 hours to 1-2 weeks of project work in groups (INSPIRE, 2008).

The in-service training courses introduce teachers to the innovative utilization of lesson units on renewable energy and efficient energy use for the benefit of learning at school. The courses also emphasize training on combining non-formal learning with curricula, considering the specific needs of teachers and curricular education, as well as the demand placed on future employees with key competences and the joy of lifelong learning.

This study aims to illuminate the features of in-service teacher training course implementation and course effects evaluation in the context of Latvia to provide detailed illustrations and examples for those who would be interested in the design and implementation of similar courses in other contexts.

\section{In-service teacher training course: Structure and content aspects}

Lately, the debates on the main components of teacher education programmes with regard to the reorientation of teacher education to address sustainability have been promoted at national and international levels (UNESCO, 2005), including the evaluation and reorientation of the main topics, content/meta-content and objectives and goals of educational programmes. The content of the teacher education curriculum is conditioned by the development of knowledge and skills defined in the teacher professional standards and associated with attributes of study courses and teaching speciality, while the metacontent contains the attitudes, values and way of thinking that is an important component of the content for sustainability.

The in-service teacher training course that is presented in this article comprised nine subsequent stages interwoven with critical reflection, feedback and assessment by all parties involved:

1) design of the course;

2) selection and motivation of the course participants;

3) pilot of the course with the teachers' feedback;

4) improvement of the structure and content of the course;

5) teacher training course (Day 1); 
6) implementation of the lesson units by the course participants at their schools;

7) completion of the questionnaire after the implementation of the lesson units;

8) teacher training course (Day 2);

9) data processing, analysis and interpretation.

Stages 1, 2, 4 and 9 were conducted solely by the project team/teacher trainers, Stages 6 and 7 were entrusted to teachers, while Stages 3, 5 and 8 were implemented in collaboration between the teacher trainers and the teachers. We will start with the description of the content aspects of training, and then we will turn to the feedback and assessment of the entire the course.

\section{Teacher training}

The teacher training was conducted during the Stages 3, 5 and 8. It included one pilot course (Stage 3) and main in-service teacher training course for three different groups of teachers starting from February to July 2009 (Stages 5 and 8). The length of the pilot course was 3.5 hours, while the main training courses were organized as two-day sessions (3.5-4 hours per day) with about a month in between the sessions. After each training session, feedback was obtained and analysed and the next training was improved according to the feedback from the teachers and the analysis performed by the course leaders. Each participant received the package of the course materials and the materials on teaching sustainability.

Day 1 of the course (Stage 5) started with the introduction to the course, information on and distribution of the course materials and a short insight in the project INSPIRE. Afterwards, several themes were presented in an interactive manner using discussions, games and demonstrations regarding: the difference between the formal and non-formal education, resources and the quality of life, climate change and energy in the school of the 21st century, pedagogical diversity in primary and secondary school and the importance of educational environment. The themes were selected so as to cover the main innovative aspects of the project INSPIRE. After the break, the lesson units were introduced to the teachers. They were motivated to implement the units in their classes and to complete a questionnaire on the implementation of the units. At the closure, the teachers were invited to discuss the relevant issues, ask questions and plan for the future work.

After a month or two, Day 2 of the training course started with introduction, followed by the oral reports and a focus group discussion of the teachers on the implementation of the lesson units in their classes. The teachers submitted the completed questionnaires and then filled out a new survey on the quality of the teacher training course and the materials. The course was closed with the teachers' questions, wishes for all participants and course leaders and the plans for follow-up of the course. The full description and the materials of the teacher training course in English and Latvian are available on the INSPIRE website (INSPIRE, 2008).

\section{Lesson units}

Innovative lesson units, created in the framework of this project, support scientific education, as well as environmental knowledge, social competences and the awareness 
of social responsibility. Although each unit has its own features in relation to the subject knowledge, all units envisage the mastering of knowledge by playing games, obtaining practical experience, participating in discussions. With regard to social competences, all units ensure the acquisition of collaboration, presentation and evaluation skills. All of them, in one way or another, offer the possibility of personal involvement in practical out-of-school/school activities with the following evaluation of the obtained results.

The units aim to inspire teachers to use the methods typical for out-of-school educational places as to achieve better learning results in school lessons. Therefore, the units were created as an invitation to borrow the elements of the student-centred teaching/ learning approach and the environment traditional for non-formal education and to accommodate them in formal settings. The methods used in the lesson units were: mind maps, brainstorming, cooperative learning, demonstrations, discovery learning, handson-learning, discussions, learning communities, project-based learning, use of multimedia, simulations, games, etc.

The description of each unit (INSPIRE, 2008) consists of the main part (relation to curriculum, theoretical background, educational objectives, learning ambiance, materials, plan of the unit and review of the unit) and several appendices with auxiliary materials.

The teachers were asked to focus mainly on the lesson units created by the Latvian team considering the local context and the features of teacher work. Here is the list of Latvian lesson units, their grade level and general content:

1) Eco-house project (grades 9-12): Understanding of environmentally friendly housing and the current perspectives of the construction of such houses;

2) From seed to energy (grades 7-9): Cultivated plants, renewable energy resources, regional economic development;

3) Principles of electric energy production (grades 7-9): Renewable and nonrenewable energy resources, electric energy production, saving electric energy;

4) Be economical - save the penguin (grades 6-9): Saving energy in the household and its influence on climate preservation;

5) Alternatives for obtaining thermal energy (grades 9-12): Understanding of resources and environmentally friendly heat supply.

\section{Methodology}

The methodological approach used in this study is an integration of illustrative case study with some elements of programme implementation and programme effects case studies.

Case study methods involve an in-depth, longitudinal examination of a single instance or event. It is a systematic way of looking at what is happening, collecting data, analysing information and reporting the results. The product is a sharpened understanding of why the instance happened as it did and what might be important to look at more extensively in future research. Thus, case studies are especially well suited towards generating, rather than testing, hypotheses (Davey, 1991). In other words, a case study is a method for learning about a complex instance, based on a comprehensive understanding of that instance obtained by extensive description and analysis of that instance taken as a whole and in its context (GAO, 1990). Case studies are always subjective and non-generalizable.

Illustrative case studies primarily describe what is happening and why, in one or two instances, to show what a situation is like (GAO, 1990). As in the given case, it makes the unfamiliar familiar, avoids over-simplification of reality and gives the reader 
a common language about the topic. Following the idea of Programme Implementation case studies, this study helps to discern whether the implementation of the course was in compliance with its intent, while the similarity with Programme Effects case studies can be found in determination of the course impact and providing inference about the reasons for success within the description of this study.

\section{Data collection methods and procedure}

The current study envisaged data collection during all stages of the course. The main data collection tools conceived both in qualitative and quantitative methodology were 1 ) survey to obtain the teachers' feedback on the training course and its materials (Stage 3 and 8);2) questionnaire "Implementation of lesson units: Evaluation by teachers" (see Appendix) (Stage 7); 3) focus groups of teachers on the implementation of lesson units (Stage 8).

The survey to obtain feedback on the training course and its materials was administered to teachers at the end of the pilot course and Day 2 of the main training course. The teachers were asked to provide answers to these questions: 1) What information did you find particularly belpful for planning your teaching? 2) What other information do you need to teach the topics of climate change and conscious dealing with energy in the classroom? 3) What information was needless? 4) What did you particularly like at the training? 5) What could hamper the implementation of the learning units? 6) What could foster the implementation of the learning units?

The questionnaire was completed by the teachers after they had implemented the lesson units with their students at school. The questionnaire consisted of an introductory part collecting the general information about the teacher, the title of the delivered lesson unit and 13 questions allowing both quantitative and qualitative answers on 1) evaluation of the effectiveness of the opening situation/introduction, methods and appendices to reach the aim of the lesson unit; 2) impact of the lesson unit on the students' interest, attitudes/values; 3 ) evaluation of the teachers' time and school resources necessary for this lesson unit; 4) suggestions for improvement of the given lesson unit.

In total, three focus groups were organized - one for each main teacher training course. Since Day 2 of the training was designed to create a space for extensive evaluation, reflection and critical feedback on the training course, its materials and implementation of the lesson units, the method of the focus group allowed the teachers to share their views and comments inferred from participation in the training, work with students, practical usage of the course materials, communication with colleagues during the courses, etc. The utterances of the focus group participants were fixed in a written form by the leaders of the course so as to allow for the subsequent analysis.

The data analysis was based on the principles of quantitative and qualitative methodology. Quantitative data from the questionnaire were processed counting the answers and calculating their percentage. An inductive thematic content analysis was used in the interpretation of the qualitative data from surveys, questionnaires and focus group discussions. Appropriate textual units (single words, phrases, sentences, paragraphs, the entire text of a written answer) conveying a theme or idea were identified for coding. Similar cases were clustered in groups, and appropriate language was chosen to describe them as emergent categories. 


\section{Participants of the course}

While 51 teachers from the Latgale region of Latvia participated in the training courses, the questionnaires "Implementation of lesson units: Evaluation by teachers" were received from 44 teachers. The average age of the 11 men (from 24 to 55 years of age) was 47.6 years. The average age of the 33 women (from 24 to 75 years of age) was 45.8 years. The average length of experience in the teaching profession was 23.5 years.

The children in Latvia start their schooling at the age of 7. The school education consists of basic education (primary and lower secondary education, grades $1-9$ ) and secondary education (grades 10-12). The majority of our sample was basic school teachers $(n=24)$, while 17 teachers work both in basic and secondary school. Only 3 teachers work only in secondary school. Twenty-seven teach Physics or Mathematics and 15 teach Biology, Chemistry or other subjects. Two teachers did not mention the subject they teach.

\section{Did the course work? Feedback and assessment by the teachers}

This section discusses the results obtained from the teachers through the survey $(n=41)$, the questionnaire $(n=44)$ and the focus groups $(n=49)$, therefore providing their feedback and assessment on the different aspects of the course. The following data were obtained from the surveys and the focus groups during the pilot course and Day 2 of the teacher training course on three occasions.

\section{Positive aspects of teacher training}

First of all, the teachers recognized that they had already thought of some issues included in the lesson units, but the course gave them real encouragement for practical application. Eleven teachers $(26.8 \%)$ answered that the most effective aspect of the training was the course materials as they are "ready-made" and do not ask for lengthy preparation. Seven teachers $(17.1 \%)$ from 41 were especially fond of the responsive team delivering the course and the exciting atmosphere during the course. Several teachers $(14.6 \%)$ noted the interactive work and games during the course that provided a break from theoretical presentations. Five teachers $(12.2 \%)$ each mentioned the diversity of teaching methods and the possibility to share the experience and express their own views, while four teachers $(9.76 \%)$ recalled the reactions of the students during the implementation of the lesson units, student motivation and enjoyment.

\section{Relevance of course materials}

The teachers indicated that particularly helpful for planning their teaching was the following:

- The general quality of the course materials (included teaching methods, etc.) is very high.

- The information on energy is new, comprehensive and diverse.

- The materials are coordinated with the curricula of the respective subjects, they are topical, student-centred, more interesting and easier to memorise than dry theory; and theoretical knowledge is brought closer to real-life situations. 
- The lesson units can be used from pre-school to secondary school during typical lesson or project weeks, in any subject both at school and its surroundings, allowing them to choose new activities every time.

- The materials contain explanations of new terms and notions.

Though several teachers expressed their need for some other materials on the topic (for instance, hand-outs, visual materials) and 12 teachers suggested the amount of information was sufficient, none of the teachers said the course included needless information.

\section{Implementation of the lesson units: Impact factors}

After the analysis of textual units from the surveys and focus groups, the following categories were obtained with regard to the practical performance of the units (Table 1). To ensure the succinctness of presentation, the factors are described generalizing from the expressions of the teachers.

Table 1. Teachers' view on the implementation of the lesson units: Impact factors

\begin{tabular}{ll}
\hline \multicolumn{1}{c}{ Impeding factors } & \multicolumn{1}{c}{ Fostering factors } \\
\hline $\begin{array}{l}\text { Lack of time: 1) to acquire all the com- } \\
\text { pulsory materials according to the curri- } \\
\text { culum besides the lesson units, }\end{array}$ & $\begin{array}{l}\text { High interest and motivation for active } \\
\text { participation at the pre-school/primary } \\
\text { school age can benefit the implemen- } \\
\text { 2) to prepare for the lesson unit until the } \\
\text { tactivity becomes a habit. }\end{array}$ \\
$\begin{array}{ll}\text { Large amount of extra work for } \\
\text { teachers: studying the unit, preparing the } \\
\text { materials, etc. }\end{array}$ & $\begin{array}{l}\text { High quality of the lesson units: elaborated } \\
\text { in great detail, include necessary } \\
\text { materials, allotted time and activities. }\end{array}$ \\
\hline $\begin{array}{l}\text { Lack of material resources at school: } \\
\text { 1) to deliver the lesson unit (demonstra- } \\
\text { tion materials, etc.); } 2 \text { ) to travel to the } \\
\text { out-of-school place. }\end{array}$ & $\begin{array}{l}\text { Previous experience of many teachers } \\
\text { who already have conducted different } \\
\text { research activities in Science lessons. }\end{array}$ \\
$\begin{array}{l}\text { Extensive knowledge on science and IT: } \\
\text { not all teachers have a proper training in } \\
\text { the latest advances in Science and IT. }\end{array}$ & $\begin{array}{l}\text { Rural schools can provide a diversity of } \\
\text { learning ambiences: the units can be con- } \\
\text { ducted at school, in the forest, near a } \\
\text { river, in the schoolyard, library. }\end{array}$ \\
$\begin{array}{l}\text { Necessity to know the students' prior } \\
\text { experience before the implementation of } \\
\text { lesson units and then allowing time for } \\
\text { “filling the gaps”. }\end{array}$ & $\begin{array}{l}\text { Wide applicability of the lesson units: } \\
\text { they can be used in any school subject or } \\
\text { at any lesson. }\end{array}$ \\
\hline
\end{tabular}

The next data were collected via questionnaire completed after the implementation of the lesson units and the percentage of answers was used to quantitatively analyse these data from the teachers. 


\section{Evaluation of teachers' time and school resources for the implementation of the lesson units}

The range of time that the teachers suggested for the preparation of lesson units was from 20 minutes to four weeks, but on average they could use about 2-3 hours. This testifies that the goals were achieved for low effort lesson units.

Contrary to their expectations, the teachers $(n=44)$ were quite positive regarding the availability of the resources necessary for the implementation of the lesson units at their school: $40 \%$ of the teachers admitted that such resources are fully available, $37.8 \%$ recognized that the resources are nearly fully available, and only $22.2 \%$ of the teachers observed that they are only partly available.

According to the teachers, on average about $80.2 \%$ of the content of the lesson units can be implemented in school (ranging from $70.5 \%$ to $90 \%$ ). This number shows the successful performance of the main task of the course - the integration of teaching methods from non-formal education into the school environment.

\section{Effectiveness of the introduction, methods and appendices of the lesson units to reach the aim set}

In general, $84.4 \%$ of the teachers recognized the relevance of the lesson units for the indicated grade level, and only $15.6 \%$ suggested that the units are only partly suited for the respective grade level.

Although about a third of the sample $(26.7 \%)$ noticed that the introduction or the opening situation of the unit was very effective to motivate students for deeper inquiry of the theme, $73.3 \%$ of the teachers selected the answer rather effective for motivation, therefore challenging the unit designers to improve the motivational elements in the introduction of the units.

As to the suitability of the methods and the appendices of the lesson units to reach the aim set, the answers of the teachers were rather similar. The majority of the teachers agreed that these elements are fully appropriate $(55.5 \%$ and $57.8 \%)$, smaller numbers of the teachers $(35.6 \%$ and $28.9 \%)$ admitted that they are nearly fully appropriate and only $8.89 \%$ and $13.3 \%$ of the teachers evaluated them as partly suitable for the aim set.

\section{Impact of the lesson units on pupils' interest and attitudes/values}

The activities reported by the teachers as the most interesting for their students were different from the typical activities of formal learning: games on energy and its usage, experiments and hands-on activities, excursions to power stations and other out-ofschool places, presentations and DVDs on energy related topics and mind maps and puzzles. These activities slightly differ from the activities recognized by the teachers as the most effective means for the development of students' knowledge, skills and attitudes, such as presentations given by students, games, group discussions, research work, projects, mathematical tasks, puzzles, mind maps and brainstorming.

The great capacity of the lesson units to foster the students' attitude development/ value awareness was recognized by $76.7 \%$ of the teachers. Another $14 \%$ of them evaluated this capacity to be high, and only $9.3 \%$ of the teachers noticed this capacity to a certain degree. 
The majority of the teachers $(77.8 \%)$ admitted that the evaluation of learning achievements at the end of the unit allows students to grasp the meaning of the mastered knowledge in the context of the rational usage of energy resources to a great extent. A much smaller proportion of the teachers indicated either a high degree $(11.1 \%)$ or a certain degree $(11.1 \%)$.

\section{Summary, conclusions and future directions}

The course described in this article was implemented during a very hard time for the educational system and teachers of Latvia, with schools closing, unemployment, serious wage cuts and expectations for worsening of the situation. The social prestige of the teaching profession was and still is low. The salary levels were relatively low (EUROGUIDANCE, 2007) already before the economic crisis and the teachers themselves reported the feelings of devaluation of their work (ESF, 2007). During the course large efforts were put to develop and maintain the motivation of teachers for innovations and extra work due to the need of lesson unit implementation. At the same time, their engagement and readiness to experiment with the new approaches and materials seemed to be surprisingly high.

The feedback of the teachers on the course materials and the entire training process, as well as their assessment of the lesson units show that the teachers evaluate them very positively and see real benefits from the implementation of the course. It should be stressed that the quality of the teaching materials plays a pivotal role in the overall success of a course, especially if it helps the teachers reduce the time necessary for the preparation for lessons. Interestingly, the teachers were much more pessimistic regarding the availability of the resources for the implementation of the lesson units at their schools before the implementation of the lesson units. After working with students they recognized that the situation is better than expected. In general, the teachers highly evaluated the effectiveness of the introduction, methods, appendices and the evaluation of the learning achievements of the lesson units, as well as their capacity to foster the development of students' attitude and meaningful knowledge in the context of the rational usage of energy resources.

The observation that the teachers were more focused on the quality and topicality of the course materials, while the student-centred orientation of the lesson units was emphasized less often, might be attributed to the current situation of Latvia's teachers having taken courses on student-centred methods more than a decade ago. It seems that they do not perceive these methods as something entirely new. As the interactive games with the teachers during the training course revealed, the teachers are well aware of the diversity of teaching methods and the need for student-centred approaches in their teaching.

To make conclusions for this illustrative case, the reflections of the course designers and implementers on the process and the results would be of certain value. So, while performing the activities of the course, the designers and implementers learned some important lessons on project team work - the benefits of cross-faculty expertise, mentoring and mature interpersonal relationships, the necessity for sophisticated motivational strategies and matching the competence of the team member with the work to be done. Also, the lesson on the creative activities and the approbation of their results was significant as the team members recognized that not all creative innovations, 
although designed acknowledging the real situation in the educational system, are easily applicable in class.

Summarizing all that is mentioned above, the main results of the course implementation are:

1) proved effectiveness of multidisciplinary and cross-faculty project team composition and the applied strategies of creative work;

2) practically approbated teacher training materials and teacher training course that is the first course with such content and structure in Latvia;

3) innovative lesson units designed drawing on the current situation in the educational system and embedded in the Latvian context;

4) orientation of Latvian teachers and students to the topic of energy;

5) increase of Latvian teachers' susceptibility towards the cooperation with outof-school places and the usage of non-formal learning methods;

6) implementation of lesson units on energy education with 669 pupils in the Latgale region of Latvia.

As the feedback from the teachers shows, this course has endowed them with inspiration for their future work and innovations in energy education. At the same time, the inspiration has also been transferred to the entire school environment, students and, possibly, their parents. The materials of training and the lesson units are available in an electronic form for every school and teacher training institution in Latvia, but the web-materials in English - for the entire world. As the reports from different institutions, organization leaders and feedback on the disseminated material show, these materials are very timely and necessary for teachers since the managers of the educational system and educational policy makers currently start to recognize the need to integrate energy education both in formal and non-formal education.

The reasons for the success of this course are manifold; the most important are numerous:

1) From the beginning to its end, it was strongly embedded in the local context.

2) The designers of the materials and the course leaders had an appropriate and rich experience, good skills and relevant knowledge developed during their work as teacher trainers, authors of teaching materials and textbooks, international and national project leaders and participants.

3) All the materials were designed using the team approach, piloting and continuous improvement strategy.

4) The entire course was based on well-considered motivational and self-esteem building strategies.

5) In spite of economic hardships, the teachers really enjoyed the materials and activities and showed a high level of involvement.

The important aspects to look at more extensively in future research are the process and the results of the implementation of similar courses in other countries and the causes for teachers' active or passive involvement in innovative processes. Also, the links between the urgency of the topic and the motivation of the teachers to integrate this topic in their teaching and differences between the science teachers and teachers of other disciplines regarding their readiness to integrate energy in their teaching could become the issues worthwhile to deal with. 
Anita Pipere, Rudìte Grabovska and Lolita Jonāne

\section{References:}

Davey, L. (1991). The application of case study evaluations. Practical Assessment, Research \& Evaluation, 2(9). Retrieved November 20, 2009, from http:// PAREonline.net/getvn.asp? $\mathrm{v}=2 \& \mathrm{n}=9$

EC. (2006). Education on energy. Retrieved December 1, 2009, from http://ec.europa.eu/ energy/action plan energy efficiency/doc/education en.pdf

ESF. (2007). Executive summary: The status of teaching profession and ways to improve it as perceived by various target groups. Contract No. 2006/0129/VPD1/ESF/PIAA/ 06/NP/3.2.5.1./0001/0001/0504 of the National European Structural Funds programme "Creating a network for teacher in-service training".

EUROGUIDANCE. (2007). Latvia: System of education. Retrieved December 3, 2009, from http://www.viaa.gov.lv/files/news/1808/educ in latvia.pdf

GAO. (1990). Case study evaluations. US General Accounting Office Programme Evaluation and Methodology Division. GAO/PEMD-91-10.1.9.

INSPIRE. (2008). Inspire school education by non-formal learning. Retrieved December 8, 2009, from http://www.inspire-project.eu/

INSPIRE. (2009). INSPIRE project handbook. Hamburg University of Applied Science: Schuethedruck, Hamburg.

Jonāne, L., \& Salitis, A. (2009). Non-formal energy education in the context of sustainability: Perspective of Latvian educators. Journal of Teacher Education for Sustainability, 11(1), 65-74. DOI: 10.2478/v10099-009-0033-2.

Kravale-Paulina, M., \& Kokina, I. (2010). The integration of formal and non-formal education: Views of Latvian educators. Discourse and Communication for Sustainable Education, 1, pp. 66-78.

Pipere, A., Jonāne, L., Salītis, A., Kokina, I., Grabovska, R., \& Kravale-Paulina, M. (2009). Energy topic in non-formal education of Latvia. In A. Skrinda (Ed.), 7th International JTEFS/BBCC conference "Sustainable Development. Culture. Education": Research and Implementation of Education for Sustainable Development. Proceedings (pp. 49-61). Daugavpils University Academic Press "Saule".

Richardson, V. (Ed.). (2001). Handbook of research on teaching (4th ed.). WA, DC: American Educational Research Association.

UN. (1992). Press Summary of Agenda 21 - Final Text. UN Conference on Environment and Development, Rio de Janeiro, Brazil.

UNESCO. (2005). Guidelines and recommendations for reorienting teacher education to address sustainability. Education for sustainable development in action. Technical Paper No. 2. UNESCO Education Sector.

UNESCO. (2007). Good practices in education for sustainable development: Teacher education institutions. UNESCO Education for Sustainable Development. In Action Good Practices, No. 3.

UNESCO. (2009a). UNESCO World Conference on Education for Sustainable Development Proceedings. 31 March - 2 April 2009, Bonn, Germany. UNESCO/BMBF/ German Commission for UNESCO. Retrieved October 2, 2009, from http:// www.esd-world-conference-2009.org/fileadmin/download/ESD2009Proceedings EnglishFINAL.pdf

UNESCO. (2009b). UNESCO World Conference on Education for Sustainable Development. ESD Project Exhibition. Retrieved October 2, 2009, from http://www.esdworld-conference-2009.org/en/esd-projects-exhibition.html 
Appendix

QUESTIONNAIRE

Implementation of the lesson units: Evaluation by teachers

Title of the lesson unit:

When was it delivered? (date)

Grade level

Number of students

School subject/event

Please, mark the most appropriate answer for each question with $X$ and add your comments.

1. Do you think that the content of the lesson unit is suitable for the indicated grade level? Yes $\square \quad$ Partly $\square \quad$ No

2. How much time is needed for the teacher to prepare for the delivery of this lesson unit?

3. Assess the availability of the resources necessary for the implementation of the lesson unit at your school:

$\square$ Fully available

$\square$ Nearly fully available

$\square$ Partly available

$\square$ Hardly available

$\square$ Unavailable

4. Was the getting to know of the life situation/theme in the beginning of the lesson unit effective enough in order to motivate students for a deeper inquiry into this theme?

$\square$ Very effective for motivation

$\square$ Rather effective for motivation

$\square$ Not particularly effective for motivation

$\square$ Ineffective for motivation

5. Assess the suitability of the selected teaching methods for reaching the aim of the lesson unit:

$\square$ Fully appropriate

$\square$ Nearly fully appropriate

$\square$ Partly appropriate

$\square$ Hardly appropriate

$\square$ Inappropriate

6. Assess the suitability of the appendices for reaching the aim of the lesson unit:

$\square$ Fully appropriate

$\square$ Nearly fully appropriate

$\square$ Partly appropriate

$\square$ Hardly appropriate

$\square$ Inappropriate 
7. Assess how much from the content of this lesson unit (in \%) it is possible to implement in the school environment.

8. Which activities in this lesson unit seemed to be the most interesting for the students?

9. Assess the capacity of this lesson unit to foster the students' attitude development/ value awareness:

$\square$ To a highest degree

$\square$ To a great extent

$\square$ Somewhat

$\square$ Very little

$\square$ Not at all

10. Which activities of the students were the most effective for the development of their knowledge, skills and attitudes?

11. To what extent the evaluation of the learning achievements at the end of the unit allows for the students' grasping the meaning of the mastered knowledge in the context of the rational usage of energy resources?

$\square$ To a highest degree

$\square$ To a great extent

$\square$ Somewhat

$\square$ Very little

$\square$ Not at all

12. To what extent did you have a chance to implement this lesson unit?

$\square$ Fully (including visit to an out-of-school place)

$\square$ Partly (including visit to an out-of-school place)

$\square$ Partly (using all elements of the unit in school lessons)

$\square$ Partly (using several elements of the unit in school lessons)

$\square$ Partly (using the elements of the unit in class hour)

13. What would you suggest in order to improve the lesson unit?

\section{Acknowledgements:}

This study was conducted within a project funded by the European Commission's Lifelong Learning Programme (2007) by means of the COMENIUS Multilateral Projects budget line: "INSPIRE: Inspire school education by non-formal learning" (reg. no. 133862-LLP-1-DE-COMENIUS-CMP).

\section{Correspondence:}

Dr Anita Pipere, Institute of Sustainable Education, Faculty of Education and Management, Daugavpils University, Parades 1, Daugavpils, LV-5400, Latvia. Email: anita.pipere@du.lv 